\title{
Performance analysis of both sex marathon runners ranked by IAAF
}

\section{Análise do desempenho de corredores maratonistas de ambos os sexos ranqueados pela IAAF}

Anselmo José Perez ${ }^{1}$

Adilson Marques²

Kamilla Bolonha Gomes ${ }^{3}$

Abstract - Running a marathon has become the motivation to achieve success and economic independence for athletes, mainly from African countries. This feeling is more evident among the black community, considering that they have been presenting better results than white athletes. The objective of the study was to analyse the ranking of marathon runners around the world, in the last 15 years considering: 1) nationality; 2) best average time of the 100 best classified runners from the Top 100, Top 50, Top 25, Top 10 and Top 3. An analysis was made to the ranking available on the International Association of Athletics Federations (IAAF) website, for the 100 best world results for both sexes, focusing on records from 2000 to 2014. The analysis was subdivided into ranking groups (Top 3, 10, 25, 50 and 100), resulting in 3000 records. African runners, Kenyan and Ethiopian, dominate the male ranking representing $70 \%$ of the total of runners in Top 100, keeping this proportion up to Top 3. African runners, Kenyan and Ethiopian, dominate the male ranking representing $70 \%$ of the total of runners in Top 100 , keeping this proportion up to Top 3. The same is observed for females, however with a significantly lower percentage (34\%), with Japanese, Ethiopian and Kenyan (17\%) and an English athlete as the world record. The average time of a marathon has been decreasing in males more than in female competitions, both in Top 3 and Top 10, however still presenting a large gap from world records.

Key words: Athletes; Athletic performance; Running; Track and field.

Resumo - As corridas de maratona se tornaram motivantes para os atletas africanos na busca de sucesso e independência econômica. Esse sentimento é mais evidente entre a comunidade negra, considerando que apresentaram melhores resultados do que atletas brancos. Analisar o ranking dos maratonistas mundiais nos últimos 15 anos considerando: 1) a nacionalidade; 2) comportamento dos tempos médios do $1^{\circ}$ ao $100^{\circ}$ (Top100), do $1^{\circ}$ ao 50 (Top50), do $1^{\circ}$ ao $25^{\circ}$ (Top25), do $1^{\circ}$ ao $10^{\circ}$ (Top10), ou do $1^{\circ}$ ao $3^{\circ}$ (Top3). Analisou-se o ranking dos maratonistas disponivel no site da International Association of Athletics Federations (IAAF), do ano de 2000 até 0 ano de 2014, analisando-se os 100 melhores resultados do mundo a cada ano de ambos os sexos, subdivido em grupos pela colocação (Top 3, 10, 25, 50 e 100), totalizando 15 anos de estudo e 3000 dados. Os africanos (quenianos e etiopes) dominam o ranking masculino com $70 \%$ do total de corredores no Top100, sendo essa proporção mantida até o Top3. O mesmo é observado para o sexo feminino, porém com percentual bem mais baixo (34\%), tendo as japonesas entre as etiopes e quenianas (17\%), e a recordista mundial uma inglesa. O tempo médio vem reduzindo entre os homens mais do que para as mulheres, principalmente para Top3 e 10, porém ainda distantes dos recordes mundiais.

Palavras-chave: Atletas; Atletismo; Corrida; Desempenho atlético.

1 Universidade Federal do Espírito Santo. Centro de Educação Física e Desportos. Vitória, ES. Brasil.

2 Universidade de Lisboa. Faculdade de Motricidade Humana. Dafundo, Lisboa. Portugal.

3 Secretaria de Saúde da Prefeitura de Serra. Serra, ES. Brasil.

Received: October 12, 2017 Accepted: February 27, 2018 


\section{INTRODUCTION}

The marathon is the biggest Olympic sport and its growing popularity among all ages can be perceived as a legacy of the evolutionary ability of the human species to run long distances ${ }^{1}$. More than a social phenomenon characterized by the large number of participants, road running, and in particular marathons, encourage the athletes to become professional and have become the path to follow to achieve success and economic independence, mainly for runners from African countries ${ }^{2}$. It is important to highlight that this has been observed in black African athletes, considering their higher scores in comparison with white South African athletes ${ }^{3}$.

Researchers have been analysing what contributes to the athletic success $^{3-7}$, considering, economy in running, social factors, genetic predisposition $^{8}$, body composition, nutritional differences in diets among Kenyans and Ethiopians and macronutrients intake recommended for endurance athletes ${ }^{9}$, general physiological reasons ${ }^{10-12}$, and/or economy in running ${ }^{5}$, living in high altitudes ${ }^{6,7,13}$, skeletal muscle fibre composition ${ }^{14}$, and better efficiency of tendon tissues ${ }^{14-16}$, enzymatic oxidative profile ${ }^{4}$, psychological advantage ${ }^{8,15}$, higher motivation to achieve economic success ${ }^{7,8}$.

It has been observed that a great majority of the elite athletes of medium and long distances are originated from eastern Africa ${ }^{6}$, and their success is attributed not only to one significant factor, but to the combination of the variables identified above. From 1986 to 2003 the number of Europeans participating in running competitions of $800 \mathrm{~m}$ from the International Association of Athletics Federations (IAAF), has decreased to 11.7\%, while the percentage of Africans in the Top 20 has increased to $85 \%$. More than half (55.8\%) of the athletes were Kenyans, more precisely, from an ethnic group named Nilotic, from Vale do Rift in Kenya ${ }^{12}$.

Considering that the economy applied in running of Top 10 athletes is significantly higher comparing to other runners ${ }^{17}$, do the results of the marathon athletes in the IAAF ranking differ throughout the years? Moreover, is the African hegemony visible for both sexes? This study has analysed the ranking of worldwide marathon athletes in the last 15 years considering: 1 ) the nationality of the athletes in the ranking and its distribution throughout the years; 2) evolution of the results during the years, characterized by the decrease of average times; 3 ) behavior observed in the ranked groups from $1^{\circ}$ to $100^{\circ}$ (Top 100), from $1^{\circ}$ to $50^{\circ}$ (Top 50), from $1^{\circ}$ to $25^{\circ}$ (Top 25$)$, from $1^{\circ}$ to $10^{\circ}$ (Top 10$)$, or from $1^{\circ}$ to $3^{\circ}$ (Top 3 ).

\section{METHODOLOGICAL PROCEDURES}

For the present study data were collected from available data in the IAAF website (www.iaaf.org). The 100 best results from years 2000 to 2014 were analysed, considering both sexes and subdividing the results into groups by their ranking (Top 3, 10, 25, 50 e 100), resulting in a total of 3000 data. Descriptive statistics has been used to represent the percentage of 
nationalities. To compare the average number of runners in Top 100, among the most representative countries, it was performed One Way ANOVA followed by Tukey HSD post hoc test. Statistical analysis was performed using SPSS 22. The significance level was set at $\mathrm{p}<0.05$.

\section{RESULTS}

The overall results and the percentage of runners by nationality, according to the information available in IAAF ranking of the Top 100 best performances from 2000 to 2014 , is presented below.

The proportions of runners by countries, from 2000 to 2014, are presented in figure 1. Most male runners were from Kenya (54\%), Ethiopia (16\%) and France (7\%). The rest, between $2 \%$ and 3\%, were from Morocco, Italy, Japan, Spain, and Portugal. Among female, most runners were from Ethiopia (18\%), Japan (17\%), Kenya (16\%), Russia (11\%), and China (7\%). Runners from Italy, United States, Germany, and North Korea represent $2 \%$ to $3 \%$ of the ranking.
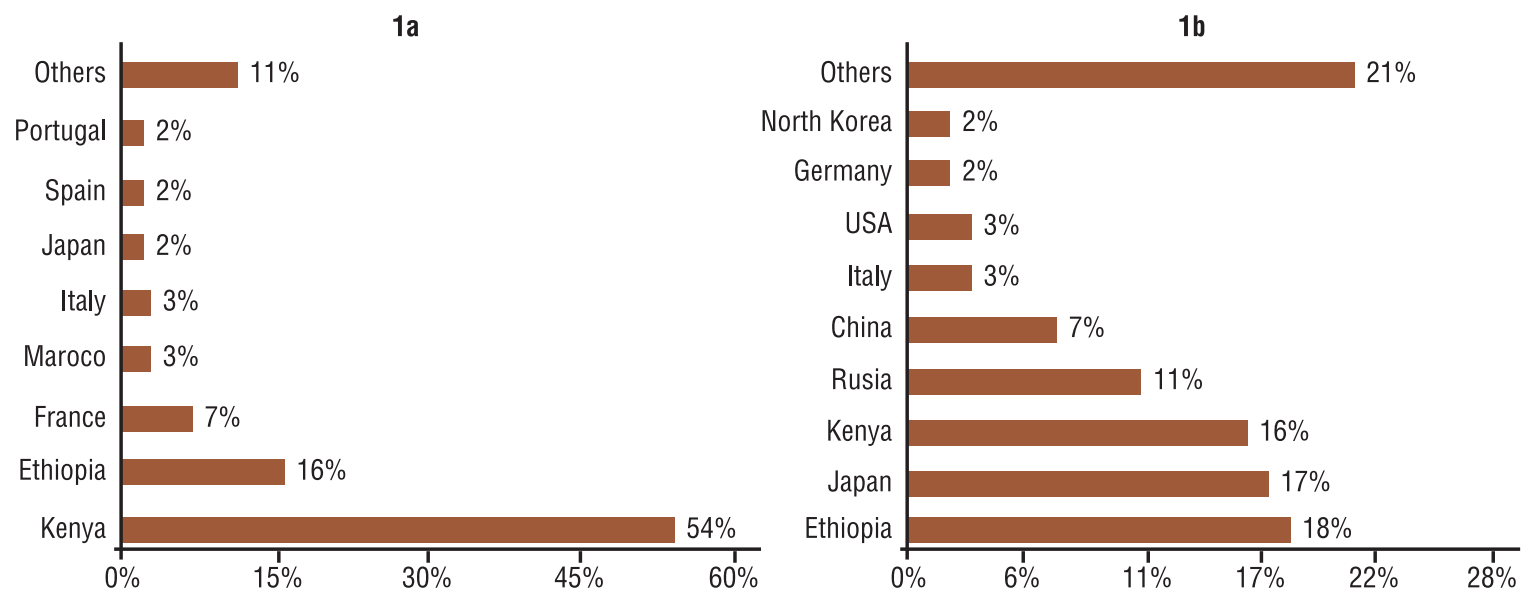

Figure 1. Nationalities of the Top 100 male (1a) and female (1b) runners from years 2000 to 2014 by percentage.

For male runners, the distribution of the most representative nationalities in Top 100 is presented in figure 2. Over the years the number of Kenyans and Ethiopians increased, and the number of French decreased, mostly in 2009, 2010, 2011 and 2012. The average of runners in Top 100 from 2000 to 2014 were $53.9 \pm 9.0$ from Kenya, 16.5 \pm 11.5 from Ethiopia, and $7.1 \pm 4.5 \%$ from France. The average of runners by countries is statistical significant $(\mathrm{F}(2,43)=112.7, \mathrm{p}<0.001)$. Tukey HSD post hoc test showed that the three countries were different from each other $(\mathrm{p}<0.001)$.

The distribution of the most representative nationalities of female runners in Top 100 is presented in figure 3. The number of Japanese runners decreased, and at the same time African runners increase. Ethiopian athletes begin to gain visibility in the last two years of the analysis (2013 and 2014), as well as Kenyan athletes in regards to Japanese runners. The average of runners in Top 100 over these period of time were 18.3 \pm 12.3 from Ethiopia, 16.5 \pm 3.8 from Japan, and 16.1 \pm 4.5 from Kenya. For female it was not observed statistical differences among countries $(\mathrm{F}(2,44)=21.5, \mathrm{p}=0.738)$. 


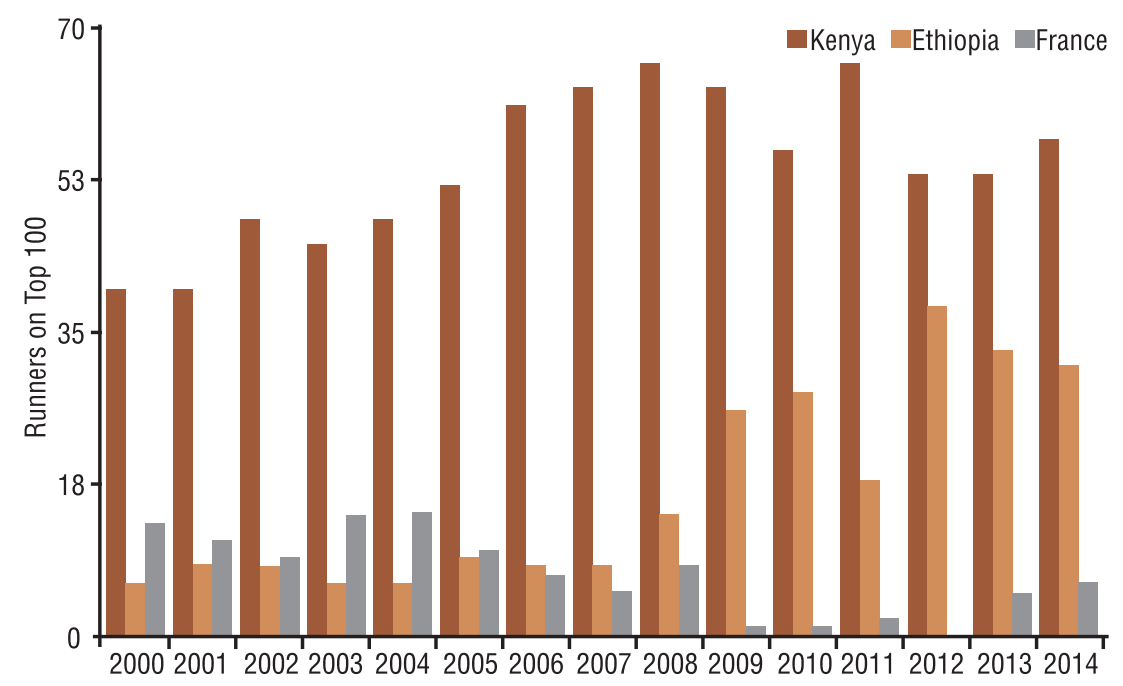

Figure 2. Distribution of the most representative nationalities in Top 100 for male runners.

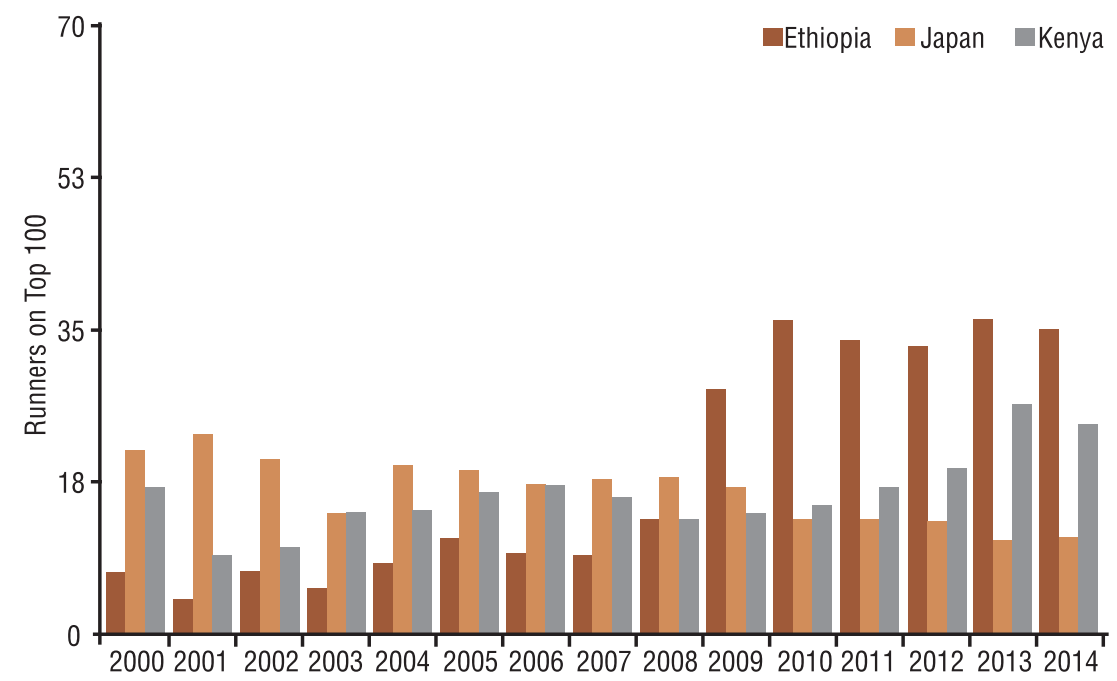

Figure 3. Distribution of the most representative nationalities in Top 100 for female runners.

Figures 4 and 5 show the average times performed by men and women respectively, from Top 100, Top 75, Top 50, Top 25, Top 10, Top 3 for each studied year. One can observe a downward trend of the average marathon time, especially among males in all Tops, except for Top 3. For women there has been a slow downward trend since 2011.

\section{DISCUSSION}

This study confirms that male athletes, Kenyans and Ethiopians, have a tendency to be well positioned based on the IAAF marathon rankings. However, and in order to better analyse this phenomena, we have looked carefully into the results of Top 3 in comparison with the other rankings. Kenyan and Ethiopian female athletes start to present the same profile as men in terms of ranking domination, with scarce representation from Japan. Contrary to what was observed for men, there is no decrease of 


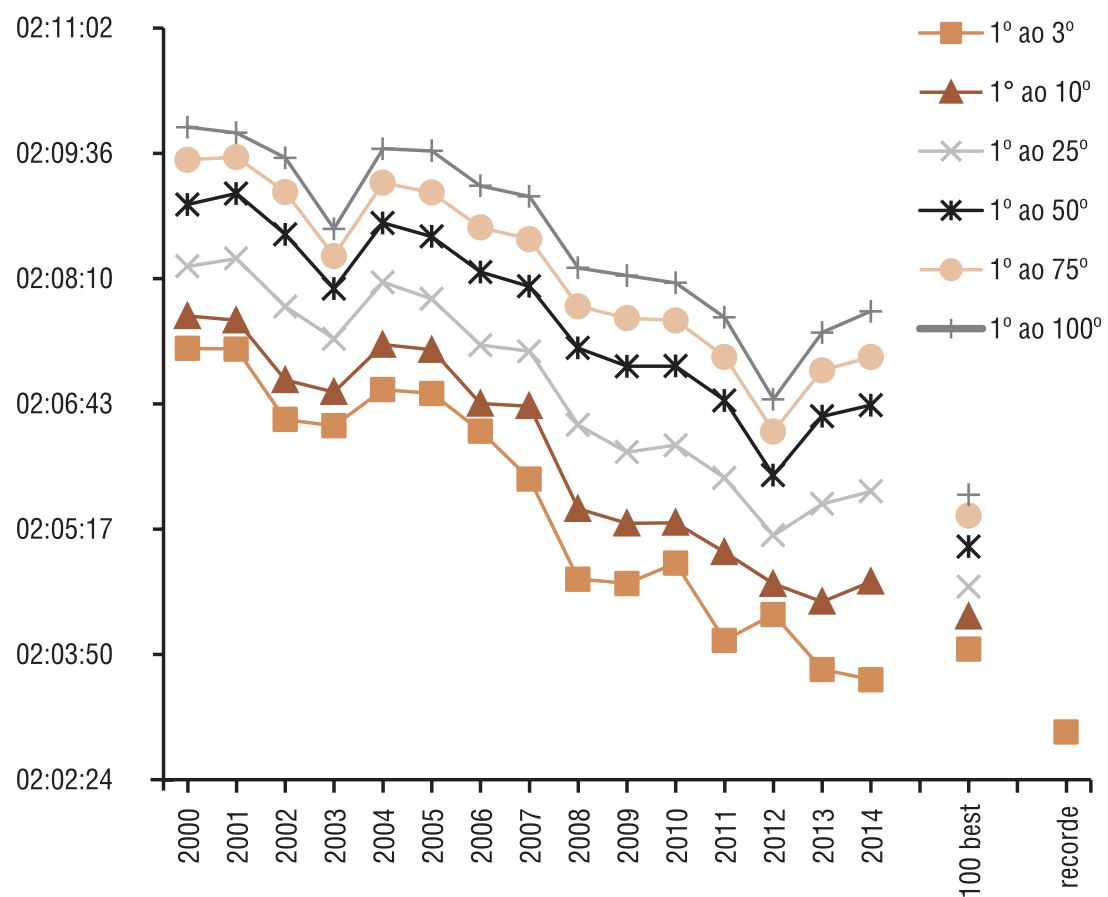

Figure 4. Male average time performed in marathons from 2000 to 2014 in accordance with ranking. The isolated dots represent the average time of the 100 best results up to that point, and to the record in each run.

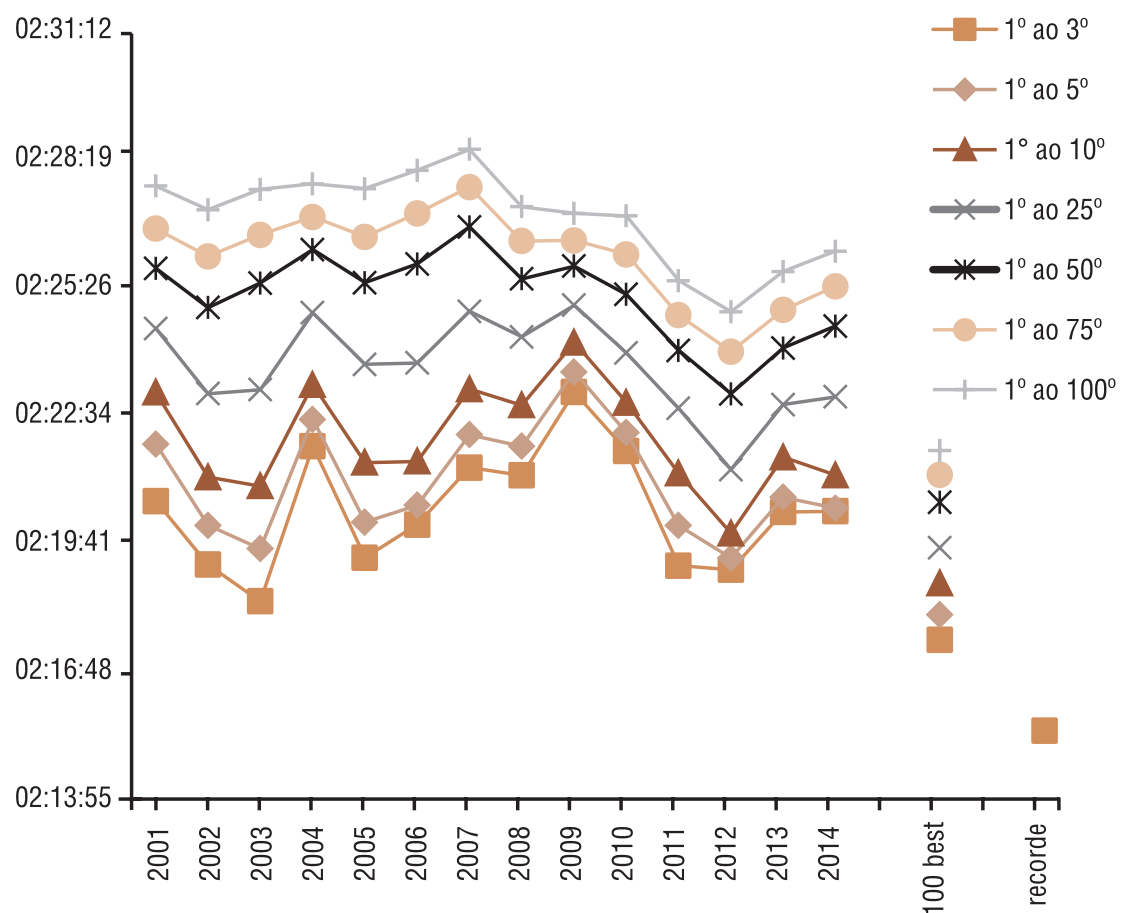

Figure 5. Female average time performed in marathons from 2001 to 2014 in accordance with ranking. The isolated dots represent the average time of the 100 best results up to that point, and to the record in each run.

average time, mainly after 2012, for Top 3 to Top 100 .

According to Hamilton ${ }^{18}$, the dominance of ranking by runners (medium and long distance) from a specific part of the world is not a new phenomenon. Research still needs to confirm if there are genetic or physiological advantages for athletes in east Africa, and it is likely that the success 
variables add up. There is a rumour that these runners are unbeatable. If this is true, it is possible that this notion gives them a psychological advantage towards their opponents ${ }^{19}$, even though their training methods are similar ${ }^{20}$.

Despite their permanent representation in the podium, Kenyan runners do not have a distinct pulmonary system to explain physiological advantage $^{21}$, or have a better diet and hydration ${ }^{9}$. Considering this, researchers have looked for other variables. According to Larsen ${ }^{22}$ there are 3 main factors in comparison to Kenyan runners and others: the use of the fraction of $\mathrm{VO}_{2 \max }$ and running economy. Moreover, their trainability is also important, however investigators have not been able to identify evidences to assert that there are indeed differences between Kenyans and Americans or Europeans. The genetic characteristics of elite Kenyan athletes seem to allow good body structure and excellent $\mathrm{VO}_{2 \max }$, which helps the economy in running and their continuity in the top runner's group ${ }^{22}$. There is no certainty though that these genetic features are the explanation for the African runners success ${ }^{10-12}$. The dominance of Kenyan runners as compared to Caucasians cannot be explained by differences in the energy parameters of running such as maximal oxygen uptake, speeds in maximum oxygen consumption and lactate threshold, and sustained fraction of the maximum oxygen consumption ${ }^{23}$. Noakes ${ }^{19}$ observed that for elite Kenyan athletes, fast running can be attributed to the number of muscle motor units in their lower members during competition.

Despite these findings regarding elite African athletes, when observing Nandi children from Kenya cities and villages ${ }^{24}$, no differences were observed in the trainability regarding $\mathrm{VO}_{2 \max }$, economy in running, sub maximal heart rate and blood lactate and ammonia concentration. There is no available information regarding the economy related to running on Kenyan non-athletes ${ }^{25}$.

Bosch et $\mathrm{al}^{3}$ have observed that when analysing several physiological responses during a competition $(42.195 \mathrm{~km})$, South African runners, when compared with other white athletes, presented clear differences in their running ability with higher $\mathrm{VO}_{2}$ max percentages. This has also been observed when running longer than $3 \mathrm{~km}$, African runners have shown higher fatigue resistance ${ }^{26}$.

Wilber and Ptsiladis ${ }^{7}$ observe that the success of Kenyans and Ethiopian runners is not based on one single genetic or physiological characteristic. On the contrary, it appears to be the result of favourable somatotype characteristics that would lead to an exceptional biomechanical and metabolic condition allowing a better running efficiency; chronic exposure to altitude combined with moderate volume and high intensity training; and a strong psychological motivation to succeed athletically

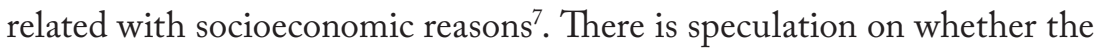
low body mass index (BMI) of Kenyan elite athletes is associated with thinner body members (long and slim legs) when compared with white runners, and if that is related with their higher ability to apply economy in running. Nonetheless, no differences have been found in their diet. The total consumption of proteins and amino acid ingestion of Kalenjin runners is within the normal recommendation for high endurance athletes, as well as carbohydrates ingestion, considering a slight variety in food ${ }^{27}$. 
Kenya has a high unemployment and poverty rate. Becoming an athlete at a competition level corresponds to financial stability, offering Kenyans a way out of poverty ${ }^{12}$. Runners from eastern Africa prefer more profitable competitions in Europe, North America and Asia ${ }^{16}$.

Regardless of the advantage African runners might demonstrate compared with other athletes ${ }^{28}$, there is still a need to identify effective training methods to enhance the individual performance, break records, or to improve the perspective of winning medals ${ }^{20}$. Despite the limited information available, Midgley et al. ${ }^{29}$ believe that researchers can still propose training recommendations from a set of data obtained in recent studies, provided that it is done with caution due to the scarce amount of information. This would implicate more effective training methods to long distance runners. Considering all findings, the factors that make an endurance athlete become an elite runner are still unclear and require further study ${ }^{30}$.

\section{CONCLUSION}

This study results highlight the dominance of the African runners. Kenyan and Ethiopian dominate the male competitions, representing $70 \%$ of the total of runners in Top 100, keeping this proportion up to Top 3. The same was observed for females, however with a significantly lower percentage. Considering that African runners share some biological aspects, some must be impelled to think that there are some genetic aspects that contribute to this dominance. However, so far there is no sufficient evidence to conclude that. The motives behind African athletes performance seem to go beyond the racial, physiological and biomechanical reasons. Therefore, there is a need for future studies that should focus on environmental, social, cultural, and economic factors in order to understand the real factors behind the African runners' performances in recent years.

\section{REFERENCES}

1. Lieberman DE, Bramble DM. The evolution of marathon running. Sports Med 2007;37(4-5):288-90.

2. Cribari M, Rüst CA, Rosemann T, Onywera V, Lepers R, Knechtle B. Participation and performance trends of East-African runners in Swiss half-marathons and marathons held between 2000 and 2010. BMC Sports Sci Med Rehabil 2013;5(24):1-14.

3. Bosch AN, Goslin BR, Noakes TD, Dennis SC. Physiological differences between black and white runners during a treadmill marathon. Eur J Appl Physiol 1990;61(1-2):68-72.

4. Prommer N, Thoma S, Quecke L, Gutekunst T, Völzke C, Wachsmuth N, et al. Total haemoglobin mass and blood volume of elite Kenyan runners. Med Sci Sport Exer 2010;42(4):791-7.

5. Weston AR, Mbambo Z, Myburgh KH. Running economy of African and Caucasian distance runners. Med Sci Sports Exerc 2000;32(6):1130-4.

6. Billat V, Lepretre PM, Heugas AM, Laurence MH, Salim D, Koralsztein JP. Training and bioenergetic characteristics in elite male and female kenyan runners. Med Sci Sports Exerc 2003;35(2):297-304.

7. Wilber RL, Pitsiladis YP. Kenyan and Ethiopian distance runners: what makes them so good? Int J Sports Physiol Perform 2012;7(2):92-102. 
8. Onywera VO. East African runners: their genetics, lifestyle and athletic prowess. Med Sport Sci 2009;54:102-9.

9. Beis LY, Willkomm L, Ross R, Bekele Z, Wolde B, Fudge B, et al. Food and macronutrient intake of elite Ethiopian distance runners. J Int Soc Sports Nutr 2011;19(8):1-7.

10. Scott RA, Moran M, Wilson RH, Onywera V, Boit MK, Goodwin WH, et al. No association between Angiotensin Converting Enzyme (ACE) gene variation and endurance athlete status in Kenyans. Com Biochem Physiol Part A 2005;141(2):169-75.

11. Scott RA, Wilson RH, Goodwin WH, Moran M, Georgiades E, Woldec B, et al. Genotypes and distance running: clues from Africa. Sports Med 2007;37(4-5):424-7.

12. Onywera VO, Scott RA, Boit MK, Pitsiladis YP. Demographic characteristics of elite Kenyan endurance runners. J Sports Sci 2006; 24(4):415-22.

13. Saltin B, Larsen H, Terrados N, Bangsbo J, Bak T, Kim CK, et al. Aerobic exercise capacity at sea level and at altitude in Kenyan boys, junior and senior runners compared with Scandinavian runners. Scand J Med Sci Sports 1995;5(4):209-21.

14. Weston AR, Karamizrak O, Smith A, Noakes TD, Myburgh KH. African runners exhibit greater fatigue resistance, lower lactate accumulation, and higher oxidative enzyme activity. J Appl Physiol 1999;86(3):915-23.

15. Baker J, Horton S. East African running dominance revisited: a role for stereotype threat? Br J Sports Med 2003;37(6):553-5.

16. Harm C, Knechtle B, Rüst AC, Rosemann T, Lepers R, Onywera V. Performance of Kenyan athletes in mountain versus flat marathon running - An example in Switzerland. J Hum Sport Exerc 2013;8(4):881-93.

17. Billat VL, Demarle A, Slawinski J, Paiva M, Koralsztein JP. Physical and training characteristics of top-class marathon runners. Med Sci Sports Exerc 2001;33(12):2089-97.

18. Hamilton B, Weston A. Perspectives on East African middle and long distance running. J Sci Med Sport 2000;3(4):VI-VIII.

19. Noakes TD. Commentary to accompany: training and bioenergetic characteristics in elite male and female Kenyan runners. Med Sci Sports Exerc 2003;35(2):305-6.

20. Midgley AW, McNaughton LR, Wilkinson M. Is there an optimal training intensity for enhancing the maximal oxygen uptake of distance runners? Sports Med 2006;36 (2):117-32.

21. Foster GE, Koehle MS, Dominelli PB, Mwangi FM, Onywera VO, Boit MK, et al. Pulmonary Mechanics and Gas Exchange during Exercise in Kenyan Distance Runners. Med Sci Sports Exerc 2014;46(4):702-10.

22. Larsen HB. Kenyan dominance in distance running. Comp Biochem Physiol Part A 2003;136(1):161-70.

23. Tam E, Rossi H, Moia C, Berardelli C, Rosa G, Capelli C, et al. Energetics of running in top-level marathon runners from Kenya. Eur J Appl Physiol 2012;112(11):3797-806.

24. Larsen HB, Nolan T, Borch C, Søndergaard H. Training response of adolescent Kenyan town and village boys to endurance running. Scand J Med Sci Sports 2005:15(1):48-57.

25. Larsen HB, Christensen DL, Nolan TN, Sondergaard H. Body dimensions, exercise capacity and physic al activity level of adolescent Nandi boys in western Kenya. Ann Hum Biol 2004;31(2):159-173.

26. Coetzer P, Noakes TD, Sanders B, Lambert MI, Bosch AN, Wiggins T, et al. Superior fatigue resistance of elite black South African distance runners. J Appl Physiol 1993;75(4):1822-7.

27. Christensen DL, van Hall G, Hambraeus L. Food and macronutrient intake of male adolescent Kalenjin runners in Kenya. Br J Nutr 2002;88(6):711-7.

28. Foster C, Lucia A. Running Economy: the forgotten factor in elite performance. Sports Med 2007;37(4-5):316-9.

29. Midgley AW, McNaughton LR, Jones AM. Training to enhance the physiological determinants of long-distance running performance. Sports Med 2007;37(10):857-80.

30. Myburgh KH. What makes an endurance athlete world class: not simply a physiological conundrum. Comp Biochem Physiol Part A 2003;136(1):171-90.

\section{CORRESPONDING AUTHOR}

Anselmo José Perez

Av. Fernando Ferrari, 514,

Goiabeiras.

CEP 29075-910, Vitória, ES, Brasil.

E-mail: anselmo.perez@ufes.br 